\title{
The effect of metabolic syndrome on recurrence in patients who had undergone surgery for carpal tunnel syndrome
}

\author{
Karpal tünel sendromu nedeniyle cerrahi geçiren hastalarda \\ metabolik sendromun nüks üzerine etkisi
}

\author{
Ersin Kasım Ulusoy, MD., ${ }^{1}$ Alper Çıraklı, MD., ${ }^{2}$ Yakup Ekinci, MD. ${ }^{3}$ \\ 'Department of Neurology, Kayseri Training and Research Hospital, Kayseri, Turkey \\ ${ }^{2}$ Department of Orthopedics and Traumatology, Medical Faculty of Ordu University, Ordu, Turkey \\ ${ }^{3}$ Department of Orthopedics and Traumatology, Kayseri Training and Research Hospital, Kayseri, Turkey
}

\begin{abstract}
Objectives: This study aims to investigate whether or not metabolic syndrome (MS) affects recurrence in patients who had undergone surgery for carpal tunnel syndrome (CTS).

Patients and methods: The study included 86 hands of 78 patients (19 males, 59 females; mean age 52.0 \pm 8.2 years; range 36 to 78 years) who underwent CTS surgery. Patients were examined clinically and demographically for the presence of MS. Patients were also evaluated using a visual analog scale and the Boston Carpal Tunnel Syndrome Questionnaire. Diagnoses of recurrence were established using electromyography in patients with clinical CTS and Tinel and/or Phalen test positivity. The effect of MS on recurrent CTS was examined statistically by independent t-test.
\end{abstract}

Results: At the end of a mean follow-up period of $36.2 \pm 19.2$ months (range 12 to 60 months), recurrence was identified in 31 $(36 \%)$ of the 86 hands. Of these 31 hands, MS was present in $23(74.2 \%)$. In the 55 hands $(64 \%)$ without recurrence, MS was present in $10(18.2 \%)$. According to these differences, the effect of MS on recurrent CTS was statistically significant $(\mathrm{p}<0.001)$.

Conclusion: Our study indicated that MS affected recurrence in patients who had undergone CTS surgery.

Keywords: Carpal tunnel syndrome; metabolic syndrome; recurrence; surgical treatment. öz

Amaç: Bu çalışmada karpal tünel sendromu (KTS) nedeniyle cerrahi geçiren hastalarda metabolik sendromun (MS) nüksü etkileyip etkilemediği araştırıldı.

Hastalar ve yöntemler: Çalışmaya KTS cerrahisi geçiren 78 hastanın (19 erkek, 59 kadın; ort. yaş 52.0 \pm 8.2 yıl; dağılım 36-78 yıl) 86 eli dahil edildi. Hastalar MS varlığ açısından klinik ve demografik olarak incelendi. Hastalar ayrıca görsel ağrı ölçeği ve Boston Karpal Tünel Sorgulama Anketi ile değerlendirildi. Klinik KTS ve Tinel veya Phalen testi pozitif olan hastalarda nüks tanıları elektromiyografi kullanılarak konuldu. Metabolik sendromun nükseden KTS üzerine etkisi istatistiksel olarak bağımsız t testi ile incelendi.

Bulgular: Ortalama 36.2 \pm 19.2 aylık (dağılım 12-60 ay) takip süresinin sonunda 86 elin 31'inde (\%36) nüks saptand. Bu 31 elin 23'ünde (\%74.2) MS vardı. Nüks olmayan 55 elin (\%64) 10'unda (\%18.2) MS vardı. Bu farklılıklara göre, MS'nin nükseden KTS'ye etkisi istatistiksel olarak anlamlı idi $(\mathrm{p}<0.001)$.

Sonuç: Çalışmamız KTS cerrahisi geçiren hastalarda MS'nin nüksü etkilediğini gösterdi.

Anahtar sözcükler: Karpal tünel sendromu; metabolik sendrom; nüks; cerrahi tedavi.

- Received: March 28, 2017 Accepted: June 21, 2017

- Correspondence: Ersin Kasım Ulusoy, MD. Develi Hatice Muammer Kocatürk Devlet Hastanesi Nöroloji Kliniği, 38400 Develi, Kayseri, Turkey Tel: +90 506-6689392 e-mail: ersinkasim_ulusoy@hotmail.com 
Carpal tunnel syndrome (CTS) is a clinical state caused by peripheral nerve entrapment neuropathy commonly observed in the upper extremities due to compression of the median nerve at the wrist within the carpal tunnel. ${ }^{[1]}$ Although the etiology of CTS is not fully known, risk factors, such as repetitive use of the wrist, advanced age, obesity, pregnancy, acromegaly, trauma, amyloidosis, diabetes mellitus (DM), kidney disease, thyroid disease and osteoarthritis were reported to be responsible. ${ }^{[2]}$

Carpal tunnel syndrome is most frequently observed in the age range of 40 to 74 years, and the general prevalence in the population is 2.7 to $5.8 \%{ }^{[3]}$ However, CTS is observed at rates that are 10-fold higher in females than in males. ${ }^{[4]}$ The diagnosis of CTS is established based on patient history, clinical signs and findings from electrodiagnostic test. ${ }^{[2,4]}$ The most common specific clinical signs of CTS are nighttime pain in the first three fingers, paresthetic complaints, such as burning, stinging and numbness, and weakness and itching in the palm of the hand. ${ }^{[3]}$ Pain may be reflected in the arm and shoulder. ${ }^{[5]}$ Carpal tunnel syndrome surgery is the most frequent treatment modality for moderate or severe CTS. ${ }^{[6]}$ The rates of recurrence after CTS surgery vary from 3 to $20 \%{ }^{[2]}$

Metabolic syndrome (MS) is a disorder that combines insulin resistance, impaired glucose tolerance, DM, abdominal obesity, dyslipidemia and hypertension (HT). ${ }^{[2]}$ Metabolic syndrome causes damage to the median nerve due to ischemic injury. The frequency of CTS in patients with MS is three times higher than in those without MS. ${ }^{[7]}$ Hence, in this study, we aimed to investigate whether or not MS affects recurrence in patients who had undergone surgery for CTS.

\section{PATIENTS AND METHODS}

The study included 86 hands of 78 patients (19 males, 59 females; mean age $52.0 \pm 8.2$ years; range 36 to 78 years) who underwent surgery for CTS at Develi State Hospital between January 2009 and January 2014 and had a postoperative follow-up period of $36.2 \pm 19.2$ months (range 12 to 60 months). Exclusion criteria were symptoms continuing postoperatively and conditions other than MS that could cause neuropathy (e.g., kidney failure, acromegaly, mucopolysaccharidosis, plexus injury or undergoing chemotherapy). The study protocol was approved by the Medical Faculty of Erciyes University Ethics Committee. A written informed consent was obtained from each patient. The study was conducted in accordance with the principles of the Declaration of Helsinki.
Electromyelography (EMG) was performed on patients with clinical CTS and Tinel and Phalen tests positivity. The recurrence of CTS was clinically evaluated with the Boston Carpal Tunnel Syndrome Questionnaire (BCTSQ) and with EMG. Then, patients were separated into two groups as those with or without recurrence. All patients were questioned for age, gender, occupation, place of residence, level of education, surgery time, dominant hand, lesion side, visual analog scale (VAS), and Tinel and Phalen tests.

Hormonal and biochemical blood tests were performed for the evaluation of MS. Patients were weighed (in $\mathrm{kg}$ ) and their heights were measured (in $\mathrm{m}$ ), then their body mass index was calculated in $\mathrm{kg} / \mathrm{m}^{2}$. Also, the presence or absence of HT was recorded. The diagnosis of MS was established based on the criteria recommended by the MS Working Group of the Turkish Endocrinology and Metabolism Association of 2005 (Table I). ${ }^{[7]}$

The BCTSQ consists of two parts, the Symptom Severity Scale (SSS) and the Functional Status Scale (FSS). The SSS includes 11 items, and the FSS includes eight items. For each item, there are five separate possible responses scored from 1 to 5 . The mean score is obtained by dividing the total score by the number of items. The mean scores for the SSS and FSS were calculated separately. ${ }^{[6]}$ In the current study, for illiterate patients, the questions were asked by the neurologist who performed the evaluation. Pain severity was assessed with a VAS for which the patients were asked to indicate the level of pain experienced on a $10 \mathrm{~cm}$ horizontal line. The provocative Tinel and Phalen tests were performed to support the CTS diagnosis.

For the electrophysiological evaluation, a Nihon Kohden (Nihon Kohden Corp., Tokyo, Japan) 4-channel electroneuromyography device was used. Sensory nerve action potentials were recorded orthodromically

\section{TABLE}

Diagnostic criteria of metabolic syndrome

\footnotetext{
At least one of the following:

- Impaired glucose tolerance

- Insulin resistance

At least two of the following:

- Hypertension (blood pressure $\geq 130 / 85 \mathrm{mmHg}$ or taking antihypertensive medication)

- Hypertriglyceridemia (triglycerides $\geq 150 \mathrm{mg} / \mathrm{dL}$ or $\mathrm{HDL}$ $<40 \mathrm{mg} / \mathrm{dL}$ in males and $<50 \mathrm{mg} / \mathrm{dL}$ in females)

- Central obesity (body mass index $>30 \mathrm{~kg} / \mathrm{m}^{2}$ or waist circumference $>94 \mathrm{~cm}$ in males and $>80 \mathrm{~cm}$ in females)

HDL: High density lipoprotein.
} 
TABLE II

Demographic characteristics of study patients

\begin{tabular}{lcccc}
\hline & $\mathrm{n}$ & $\%$ & Mean \pm SD & Range \\
\hline Age (year) & & & $52.0 \pm 8.2$ & $36-78$ \\
Gender & 59 & 75.6 & & \\
$\quad$ Female & 19 & 24.4 & & \\
$\quad$ Male & & & \\
Occupation & 26 & 33.3 & \\
$\quad$ Farmer & 27 & 34.6 & \\
$\quad$ Housewife & 22 & 28.2 & \\
$\quad$ Labourer & 3 & 3.8 & \\
$\quad$ Clerk & & & \\
Place of residence & 61 & 78.2 & \\
$\quad$ Town & 17 & 21.8 & & \\
$\quad$ Village & & & & \\
Level of education & 54 & 69.2 & \\
$\quad$ Primary school & 17 & 21.8 & & \\
$\quad$ High school & 7 & 9.0 & & \\
$\quad$ Illiterate & & & & \\
Postoperative follow-up period (month) & & &
\end{tabular}

by surface disc electrodes. In the median nerve sensorial conduction studies, the stimulation were applied to the index finger and sensory nerve action potential was recorded in the wrist. For median nerve motor conduction, stimulation was performed in the wrist and elbow, and the compound muscle action potential was recorded from the thenar eminence, with the active recording electrode placed over the belly of the abductor pollicis brevis and the reference electrode over the abductor pollicis brevis tendon. The potential peak amplitude of the sensory nerve axon, the conduction velocity of the sensory nerve fibrils, the potential peak amplitude of the motor nerve axon, the distal motor latency and the conduction velocity of the motor nerve fibrils were measured. The diagnoses were established according to the criteria of the American Association of Electrodiagnostic Medicine. ${ }^{[8]}$ The level of CTS was categorized as mild, moderate or severe based on our own laboratory normal values from electrodiagnostic studies. ${ }^{[9]}$

\section{Statistical analysis}

The statistical analyses of the study data were performed with IBM SPSS version 21.0 (IBM Corp.,

TABLE III

Factors affecting development of recurrence in patients who underwent surgery for carpal tunnel syndrome

\begin{tabular}{|c|c|c|c|c|c|c|c|}
\hline & \multicolumn{3}{|c|}{ No recurrence $(n=55)$} & \multicolumn{3}{|c|}{ Recurrence $(n=31)$} & \multirow[b]{2}{*}{$p$} \\
\hline & $\mathrm{n}$ & $\%$ & Mean \pm SD & $\mathrm{n}$ & $\%$ & Mean $\pm S D$ & \\
\hline Age (year) & & & $51.5 \pm 9.3$ & & & $54.2 \pm 6.4$ & 0.152 \\
\hline Occupation & & & & & & & 0.877 \\
\hline Farmer & 17 & 58.6 & & 12 & 41.4 & & \\
\hline Housewife & 20 & 69 & & 9 & 31 & & \\
\hline Labourer & 16 & 64 & & 9 & 36 & & \\
\hline Clerk & 2 & 66.7 & & 1 & 33.3 & & \\
\hline Dominant hand & & & & & & & 0.705 \\
\hline Right & 49 & 62.8 & & 29 & 37.2 & & \\
\hline Left & 6 & 75 & & 2 & 25 & & \\
\hline
\end{tabular}

SD: Standard deviation. 
Armonk, NY, USA) for Windows software. Numerical variables were presented as the mean \pm standard deviation, and categorical variables were presented as numbers (n) and percentages (\%). The normalities of numerical variable distributions were assessed with the Kolmogorov-Smirnov test. The similarities of group variances were analyzed with the Levene test. The differences in numerical variables between the groups were also analyzed with the t-test for independent groups when the parametric test hypotheses were met and with the Mann-Whitney $U$ test when they were not. The relationships between categorical variables were examined with the chisquare test. A value of $\mathrm{p}<0.05$ was accepted as statistically significant.

\section{RESULTS}

Of the total 78 cases, bilateral CTS was detected in eight $(10.2 \%)$, and unilateral CTS in $70(89.7 \%)$. The characteristics of the cases were provided in Table II.

Of the 86 hands, recurrence was identified in $31(36 \%)$ that underwent surgery for CTS. Metabolic syndrome was identified in $23(74.2 \%)$ of the 31 hands of patients who experienced recurrence and in $10(18.2 \%)$ of the 55 hands $(64 \%)$ without recurrence. This difference was statistically significant $(p<0.001)$.

In the hands in which recurrence developed, the VAS (7 [6-9]), SSS (3 [1.72-4.74]) and FSS (3 [1.62-4.62]) values were significantly higher than those of the hands without recurrence: the VAS (0 [0-4]), SSS (1 [1-11]) and FSS (1 [1-1.25]). The differences were statistically significant $(\mathrm{p}<0.001)$.

Analysis of factors that affected the recurrence of CTS revealed that the development of recurrence increased proportionally with the period of surgery, and this relationship was statistically significant $(p<0.001)$. However, the occupation subgroup and the use of the dominant hand did not affect significantly the development of recurrence (Table III).

\section{DISCUSSION}

In the current study, of the 86 hands, recurrence was identified in $36 \%$. In these hands, metabolic syndrome was present in $74.2 \%$, and in the hands without recurrence, metabolic syndrome was present in $18.2 \%$. The difference was statistically significant, indicating that MS may cause recurrence in patients who undergo CTS surgery.

Carpal tunnel syndrome is the most commonly observed entrapment neuropathy of the upper extremities..$^{[1,9]}$ Female gender, pregnancy, DM, rheumatoid arthritis and hypothyroidism are the most well-known etiological causes. Metabolic syndrome and its components, such as obesity and increased cholesterol levels, have recently been defined as risk factors for CTS. ${ }^{[10]}$ Although there are different data about these etiologic factors in the literature, we attempted to investigate whether or not MS affects recurrence in patients who had undergone surgery for CTS.

The diagnostic criteria for MS were defined in 1998 by the World Health Organization, and global guidelines were published in 2005 by the International Diabetic Federation with equivalent values described for different ethnic groups. ${ }^{[6,10]}$ The combination of mechanical trauma and ischemic damage is thought to cause CTS. Diabetes mellitus, HT and hyperlipidemia, particularly low-density lipoprotein cholesterol, are related to ischemic damage. ${ }^{[1]]}$ The nerves of patients with DM, which is one of the components of MS, are less resistant to extraneural pressure and are more easily entrapped. In our study, the diagnosis of MS was established based on the criteria recommended by the MS Working Group of the Turkish Endocrinology and Metabolism Association of 2005 (Table I).

In a study by Mondelli et al., ${ }^{[12]}$ the outcomes of CTS surgery for diabetic and non-diabetic patients were analyzed. Both groups exhibited good improvement in clinical and electrophysiological statuses. The improvements were not reported to be less extensive in the diabetic group. This study demonstrated how DM alone does not represent a risk factor for CTS surgery; rather, the risk increases when DM is associated with other internal diseases related to MS. Furthermore, Perkins et al. ${ }^{[13]}$ determined the CTS prevalence to be $14 \%$ in diabetic patients without diabetic polyneuropathy (DPN) and approximately $30 \%$ in diabetic patients with DPN. Similarly, in the current study, the rate of the development of CTS recurrence was higher in the patient group with MS, and the difference was statistically significant.

Carpal tunnel syndrome is observed at rates that are 10-fold higher in females than males because the carpal tunnel seems to be smaller in females than in males. The CTS incidence peaks at a mean age of 40-60 years. ${ }^{[3]}$ In a study by Yurdakul et al., ${ }^{[2]}$ the mean age was $46.3 \pm 12.2$ years, and $85.7 \%$ of the patients were female. Similarly, in the current study, CTS was observed $75.6 \%$ in females; however, the mean age of our patients was higher than the prior study (52.0 \pm 8.2 years) and its lead to high recurrence rate for the one reason. 
The dominant hand was reported to be affected first and with greater severity. ${ }^{[4]}$ In the current study, $75 \%$ of the 86 hands were of female patients. However, there was no significant difference between the dominant and non-dominant hands with respect to the development of recurrence.

Various studies conducted on MS patients have reported CTS rates from 54 to $75 \%$. The reason for this difference could be related to where the studies were conducted, i.e., if they involved rural or urban regions. Throughout the world in general, CTS risk cannot be classified according to a single occupational group. It occurs more often in assembling, manufacture activities, janitorial duties, tailor work and agricultural work. ${ }^{[13]}$ This study was conducted in a rural area and the patient group comprised individuals who used their hands a lot. Analyzing the data, it is important to take into account the contribution of these two factors in the high recurrence of CTS that they developed. ${ }^{[14]}$

To prevent recurrence after CTS surgery, important interventions, including hand-wrist exercises, taking frequent rest breaks and using a splint to hold the wrist and the hand straight in the appropriate position, should be employed. ${ }^{[14]}$ Additionally, as the number of patients with MS is currently increasing, it is also important that hyperglycemia, hyperlipidemia and obesity are controlled to prevent recurrence. A recent study conducted with Turkish adults demonstrated that the MS prevalence can vary between 36.6 and $44.0 \%{ }^{[3,14]}$ In light of this information, it is important to inform patients fully and correctly after surgery to prevent recurrence.

In a retrospective cohort study, Zieske et al. ${ }^{[15]}$ examined 97 hands that had undergone CTS revision surgery between 2001 and 2012 and the consequent follow-ups. The results revealed that DM represents a statistically significant risk factor for CTS recurrence $(p<0.005)$. In addition, the average rates of surgical error have been reported to be 3 to $19 \% .{ }^{[8]}$ In the our study, patients who exhibited no clinical recovery were excluded, which increased the power of the study. It is important for the surgeon to ascertain the patient's MS condition preoperatively so that the optimal surgical method can be selected. The application of sufficient and/or extensive loosening for MS patients can lead to a reduction in the high recurrence rate.

This study has some limitations. Firstly, all surgeries were not performed by the same surgeon. Secondly, the same surgical technique was not performed in all patients. Another limitation was that the preoperative MS status was not known, which may be an obstacle to distinguish between the effect of MS on relapse and the failure of the surgeon.

In conclusion, in this study, we highlighted that MS may affect recurrence in patients who had undergone surgery for CTS. Therefore, patients should be questioned preoperatively with respect to their MS status, educated postoperatively about the recurrence risk related to MS, and referred to the relevant departments, if necessary.

\section{Declaration of conflicting interests}

The authors declared no conflicts of interest with respect to the authorship and/or publication of this article.

\section{Funding}

The authors received no financial support for the research and/or authorship of this article.

\section{REFERENCES}

1. Ağırman M, Kara A, Durmuş O, Saral İ, Çakar E. Isokinetic evaluation of wrist muscle strength in patients of carpal tunnel syndrome. Eklem Hastalik Cerrahisi 2017;28:41-5.

2. Yurdakul F, Bodur H, Çakmak ÖÖ, Ateş C, Sivas F, Eser F, et al. On the severity of carpal tunnel syndrome: Diabetes or Metabolic Syndrome. J Clin Neuro. 2015;11:234-40.

3. Wainner RS, Fritz JM, Irrgang JJ, Delitto A, Allison S, Boninger ML. Development of a clinical prediction rule for the diagnosis of carpal tunnel syndrome. Arch Phys Med Rehabil 2005;86:609-18.

4. Tortland PD. Nonsurgical management of carpal tunnel syndrome. Tech Orthopaed 2003;18:23-9.

5. Zimmerman M, Dahlin E, Thomsen NOB, Andersson GS, Björkman A, Dahlin LB. Outcome after carpal tunnel release: impact of factors related to metabolic syndrome. J Plast Surg Hand Surg 2017;51:165-71.

6. Onat A, Can G, Çakr H, Özpamuk-Karadeniz F, Karadeniz Y, Yüksel H, et al. Sex-Specific Predictors of Metabolic Syndrome Independent of Its Components. J Investig Med 2015;63:796-801.

7. Boulton AJ, Malik RA, Arezzo JC, Sosenko JM. Diabetic somatic neuropathies. Diabetes Care 2004;27:1458-86.

8. Onder B, Yalçın E, Selçuk B, Kurtaran A, Akyüz M. Carpal tunnel syndrome and metabolic syndrome co-occurrence. Rheumatol Int 2013;33:583-6.

9. Faucher GK, Daruwalla JH, Seiler JG. Complications of Surgical Release $\backslash$ break of Carpal Tunnel Syndrome: A Systematic Review. J Surg Orthop Adv 2017;26:18-24.

10. Zimmet PZ, Alberti KG, Shaw JE. Mainstreaming the metabolic syndrome: a definitive definition. Med J Aust 2005;183:175-6.

11. Li Pi Shan R, Nicolle M, Chan M, Ashworth N, White C, Winston P, et al. Electrodiagnostic Testing and Treatment for Carpal Tunnel Syndrome in Canada. Can J Neurol Sci 2016;43:178-82.

12. Mondelli M, Padua L, Reale F, Signorini AM, Romano C. Outcome of surgical release among diabetics with carpal tunnel syndrome. Arch Phys Med Rehabil 2004;85:7-13. 
13. Perkins BA, Olaleye D, Bril V. Carpal tunnel syndrome in patients with diabetic polyneuropathy. Diabetes Care 2002;25:565-9.

14. Gundogan K, Bayram F, Gedik V, Kaya A, Karaman A, Demir O, et al. Metabolic syndrome prevalence according to ATP III and IDF criteria and related factors in Turkish adults. Arch Med Sci 2013;9:243-53.

15. Zieske L, Ebersole GC, Davidge K, Fox I, Mackinnon SE. Revision carpal tunnel surgery: a 10-year review of intraoperative findings and outcomes. J Hand Surg Am 2013;38:1530-9. 